\title{
KARAKTER ANAK DALAM KELUARGA SEBAGAI KETAHANAN SOSIAL BUDAYA BANGSA
}

\author{
Ni Wayan Suarmini, Ni Gusti Made Rai, Marsudi
}

Abstrak

\begin{abstract}
Keluarga merupakan tempat pertama dan utama bagi pertumbuhan serta perkembangan anak. Peran dan fungsi keluarga menjadi sangat penting dalam tanggung jawab terhadap pendidikan anak. Pendidikan akan mengembangkan potensi anak menjadi suatu kompetensi, yang meliputi pengetahuan, keterampilan, dan sikap. Keluarga merupakan tempat yang paling awal dan efektif untuk menjalankan fungsi pendidikan dalam menanamkan kejujuran, kedisiplinan, dan rasa tanggungjawab sebagai unsur dari karakter. Anak merupakan generasi penerus bangsa yang harus memiliki karakter yang kokoh agar mampu mengembangkan nilai-nilai budaya bangsa untuk menangkal penetrasi budaya asing yang kurang relevan.

Setiap keluarga diharapkan dapat menumbuhkan kesadaran anak, kelak dalam mengembangkan nilai-nilai budaya bangsa sebagai kekuatan dalam setiap aspek pembangunan nasional. Sumberdaya manusia yang berkarakter akan mampu mengembangkan nilai-nilai budaya bangsa dan memiliki daya saing dalam menghadapi era global.
\end{abstract}

Kata kunci :Keluarga , karakter dan sosial budaya.

Manusia secara kodrati terlahir sebagai makhluk individu dan makhluk sosial. Manusia sebagai individu memiliki kekhususaan, ciri khas, kepribadian, karakter, yang tentunya berbeda antara yang satu dengan yang lainnya. Manusia disebut sebagai makhluk yang unik, karena dari semua individu yang ada di muka bumi ini tidak satupun sama. Dalam kehidupan individu juga harus terjaga keharmonisan sebagai individu yaitu dimulai dari berfikir yang jujur dan benar, berkata yang jujur dan benar, dan berperilaku yang jujur dan benar. Dengan kata lain bahwa kehidupan harmonis bagi seorang individu adalah keseimbangan antara pikiran, perkataan dan tindakan.

Manusia tidak dapat hidup terpisah dari manusia lainnya, manusia akan memiliki makna apabila hidup di tengah-tengah manusia lainnya. Keharmonisan secara individu akan sangat memudahkan manusia menyesuaikan diri dengan lingkungannya.

Manusia secara kodrati juga sebagai makhluk sosial. Sebagai makhluk sosial seseorang individu harus hidup berdampingan dengan orang lain, bahkan makhluk hidup lainnya. Kehidupan sosial, seperti berteman, berkeluarga, jsh Jurnal Sosial Humaniora, Vol 9 No.1, Juni 2016 
bermasyarakat, bersuku, berbangsa dan bernegara. Kehidupan kelompok dapat mempengaruhi kehidupan individu, demikian juga sebaliknya. Oleh karena itu terjadi kehidupan dalam suatu komunitas, artinya berkelompok bagi yang memiliki kesamaan visi, kepentingan yang sama, kesamaan daerah asal, kesamaan keluarga, bahkan kesamaan darah, dan sebagainya. Terjadilah banyak bentuk komunitas dalam masyarakat. kehidupan pribadi tetap dapat terwujud, namun dalam hal-hal tertentu harus menurunkan atau melakukan penyesuaian dengan komunitasnya. Kalau tidak terjadi toleransi, adaptasi, dan menurunkan tempo individunya, maka tidak akan terjadi kehidupan kelompok tersebut

Menjaga hubungan baik dengan sesama, maknanya kehidupan seseorang individu harus saling membantu, menghargai, menghormati, toleransi, gotong royong dengan sesama individu lainnya. Manusia dengan kecerdasannya akan mengatur segala bentuk pikirannya. Bukan berarti pikiran yang secara kognitif diakui kecerdasannya akan serta merta berbanding lurus dengan kualitas emosional dan bahkan kepribadian yang mantap. Harapan semua pihak bahwa dengan kemampuan yang diterjemahkan dalam IQ akan didukung dengan kemantapan kepribadian dan EQ supaya tercipta individu yang matang.

Keluarga yang merupakan sistem sosial terkecil ini memberikan pengaruh besar untuk tercapai keseimbangan tersebut. Keluarga akan memberikan kesempatan terjadinya proses pendidikan dan pengembangan pribadi yang berkualitas yang terdiri dari anggotanya yaitu ayah, ibu dan anak. Keluarga sebagai lembaga pendidikan pertama dan utama bagi anak. Maknanya bahwa keluarga sebagai peletak dasar-dasar pendidikan dalam pembentukkan karakter anak. Anak sebagai generasi penerus kehidupan keluarga kelak, sehingga anak sering dipandang sebagai cerminan keluarga. Hal ini menunjukkan bahwa pendidikan dalam keluarga menjadi sangat penting mendapatkan perhatian dari anggota keluarga yang lebih dewasa. Sebenarnya bahasa ibu sangat berpengaruh terhadap pembentukkan nilai-nilai moral kepada anak. Bahasa ibu (bahasa daerah) senantiasa mengandung tata krama, sopan santun, dan unggah ungguh untuk kehidupan sosial anak. Bahasa ibu atau bahasa daerah ditinggalkan oleh generasi sekarang, terlihat jelas bagaimana anak berbicara kepada orang tua atau 
orang yang lebih tua atau orang yang dituakan. Orang tua menjadi model bagi tumbuh kembang anak-anak dalam keluarga dan masyarakat. Meniru merupakan faktor yang berkembang pada anak, karena sebagai suritauladan. Sebagaimana dikemukakan oleh Ki Hajar dewantara tokoh pendidikan Indonesia bahwa ing ngarso sung tulodo, ing madya mangun karsa, dan tut wuri handayani sebagai pendidikan karakter.

Kehidupan keluarga yang harmonis menghasilkan anak-anak bangsa yang bermoral dan berakhlak mulia. Demikian juga sebaliknya. Oleh karena itu manusia sejak awal sudah benar melakukannya, seperti diawali dengan saling mengenali satu dengan yang lainnya, proses pemilihan, dan menentukan pilihan sebagai pasangan hidup. Namun dalam perjalanan kehidupan keluarga muncul kembali kehidupan individu yang menonjolkan ego, sehingga sering terjadi keluarga tidak harmonis lagi. Pada akhirnya ketidakharmonisan keluarga akan berdampak langsung bagi perkembangan psikologis anak. Seperti pada kasus kekerasan dalam rumah tangga, menyerupakai gunung es. Puncaknya hanya terlihat sebagai bagian terkecil dari jumlah kasus yang sebenarnya. Terdapat 369 kasus sejak sepuluh bulan terakhir di tahun 2015 (Lestari, 2016). Berdasarkan banyaknya kasus kekerasan dalam rumah tangga menjadi pemicu terjadinya kemunduran dari kualitas anak bangsa yang seharusnya berakter mantap. Bahkan banyaknya kekerasan yang terjadi pada anak dilakukan oleh orang terdekat. Di layar televisi belakangan ini sering kita melihat berbagai tontonan tindak kekerasan, pelecehan seksual dan tindak kriminal lainnya, baik terjadi dalam keluarga, di sekolah, maupun di lingkungan lain. Terutama tindak kekerasan bagi anak-anak, justru terjadi pada tempat anak-anak melakukan aktivitas bermain. Peristiwa-peristiwa tersebut memunculkan pertanyaan di benak kita: "Apa yang terjadi dengan masyarakat dan bangsa ini? Bagaimana dengan pendidikan bagi generasi bangsa ini, mengapa kejadian-kejadian itu terjadi pada lingkungan yang seharusnya memberikan perlindungan pada anak-anak. Mengapa dilakukan oleh orang-orang dekat dan kenal dengan baik oleh mereka? Hal demikian bisa memunculkan adanya penyakit yang kian menjangkit masayarakat indonesia pada akhirnya menyebabkan kualitas generasi penerus yang kurang berkarakter 
mantap. Keluarga pada akhirnya menjadi tempat yang diharapkan bisa membentengi anak sebagai penerus generasi bangsa dan juga mencegah terjadinya persoalan yang semakin rumit dan kompleks.

Karakter bangsa harus terlahir dari bangsa itu sendiri. Indonesia sebagai bangsa yang besar harus memiliki karakter Indonesia, bukan karakter lain. Maka penegakkan hukum, melestarikan bahasa (daerah dan Indonesia), mentaati ajaran agama mutlak dilakukan sebagai pembenahan mental masyarakat Indonesia. Tentu dimulai dari lembaga-lembaga pendidikan, lembaga atau organisasiorganisasi kemasyarakatan, pemerintah pada lembaga-lembaga, dan semua pihak warga negara Indonesia tanpa kecuali. Konsisten menerapkan aturan, sistem, dan ajaran agama. Karakter bangsa akan terwujud dengan sendirinya sebagai bangsa yang besar dan kaya sumber daya alam dan sumber daya manusia. Tinggal memoles dengan pendidikan yang benar, berdasarkan kepribadian Indonesia, maka akan menghasilkan tenaga kerja dan pekerja yang berkarakter Indonesia.

\section{Karakter}

Pandangan para ahli beragam tentang karakter. Ada yang berpendapat bahwa karakter merupakan suatu penilaian yang subyektif terhadap kualitas moral dan mental. Ahli lain mengatakan bahwa karakter sebagai penilaian subyektif terhadap kualitas mental saja. Oleh karena itu upaya merubah atau membentuk karakter hanya berkaitan dengan stimulasi terhadap intelektual seseorang (encyclopedia, 2004). Sedangkan Coon (1983) mendefinisikan karakter sebagai suatu penilaian subyektif terhadap kepribadian seseorang yang berkaitan dengan atribut kepribadian yang dapat atau tidak dapat diterima oleh masyarakat. Menurut Megawangi (2003), kualitas karakter meliputi sembilan pilar, yaitu (1) Cinta Tuhan dan segenap ciptaan-Nya; (2) Tanggung jawab, Disiplin dan Mandiri; (3) Jujur/amanah dan Arif; (4) Hormat dan Santun; (5) Dermawan, Suka menolong, dan Gotong-royong; (6) Percaya diri, Kreatif dan Pekerja keras; (7) Kepemimpinan dan adil; (8) Baik dan rendah hati; (9) Toleran, cinta damai dan kesatuan. Jadi, menurut Ratna Megawangi, orang yang memiliki karakter baik adalah orang yang memiliki kesembilan pilar karakter tersebut. 
Pendapat para ahli di atas dapat dikemukakan bahwa karakter dipandang sebagai suatu yang sempit dan berpandangan luas. Pandangan sempit mengatakan bahwa karakter merupakan penilaian subyektif terhadap mental seseorang. Sedangkan ahli yang berpandangan luas mengatakan karakter merupakan penilaian subyektif terhadap kualitas moral dan mental, bahkan diutarakan menjadi sembilan pilar oleh Megawangi. Semua itu adalah aspek-aspek kepribadian seseorang dalam hidup sebagai pribadi dan kehidupan sosial.

Proses sosialisasi dan pendidikan (faktor nurture) sangat penting dalam pendidikan karakter. Menurut Thomas Lichona (Megawangi, 2003), pendidikan karakter penting dilakukan sejak usia dini. Erik Erikson juga menyatakan hal yang sama ia menyebutkan bahwa anak adalah gambaran awal manusia menjadi manusia, yaitu masa di mana kebajikan berkembang secara perlahan tapi pasti (dalam Hurlock, 1981). Dengan kata lain bahwa apabila dasar-dasar kebajikan gagal ditanamkan pada anak di usia dini, maka dia akan menjadi orang dewasa yang tidak memiliki nilai-nilai kebajikan. Selanjutnya, White (dalam Hurlock, 1981)menyatakan bahwa usia dua tahun pertama dalam kehidupan adalah masa kritis bagi pembentukan pola penyesuaian personal dan sosial.

Dapat disimpulkan bahwa karakter merupakan kualitas moral dan mental seseorang yang pembentukannya dipengaruhi oleh faktor bawaan (fitrah-nature) dan lingkungan (sosialisasi atau pendikan-nurture). Potensi karakter yang baik dimiliki manusia sebelum dilahirkan, tetapi potensi tersebut harus diisi nilai-nilai kebajikan secara terus-menerus melalui proses sosialisasi dan pendidikan sejak dini. Betapa penting dan urgennya proses sosialisasi dan pendidikan bagi perkembangan karakter anak sejak dini, karena belajar sepanjang hayat. Apabila salah dalam menanamkan nilai-nilai kehidupan kepada anak usia dini, maka ia akan dewasa dapat nilai yang benar untuk menuntunya menjadi harmonis atau akan rusak selamanya. Pendidikan itu yang utama dan pertama adalah di dalam keluarga.

Pada hakikatnya bahwa tugas dasar perkembangan merupakan tugas berdasarkan tahapan dasar yang setiap manusia yang dipersiapkan dalam rangka mencapai kemandirian dan mampu menghadapi tuntutan kehidupan. Dengan kata 
lain, tugas utama seseorang dalam perkembangannya adalah mempelajari "aturan main” segala aspek yang ada di dunia ini. Dengan demikian, anak harus belajar memahami aturan main dalam hubungan kemasyarakatan, sehingga ada hukum dan sanksi yang mengatur perilaku anggota masyarakat dalam kehidupan bermasyarakat.

Menurut Garbarino \& Brofenbrenner (dalam Vasta, 1992), jika suatu bangsa ingin bertahan hidup, maka bangsa tersebut harus memiliki aturan-aturan yang menetapkan apa yang salah dan apa yang benar, apa yang boleh dan apa yang tidak boleh dilakukan, apa yang adil dan apa yang tidak adil, apa yang patut dan tidak patut. Oleh karena itu, sebagai makhluk sosial perlu ada aturan, norma, kaidah, hukum yang mengatur etika dan tingkahlaku dalam bicara, berlalu lintas, dan aktivitas sosial lainnya. Jika tidak, maka hidup ini akan "kacau", karena setiap orang boleh berlaku sesuai keinginannya masing-masing tanpa harus mempedulikan orang lain (makhluk individu). Akhirnya antar sesama menjadi saling menjegal, saling menyakiti, bahkan saling membunuh, sehingga hancurlah bangsa itu.

Memahami "aturan" dalam kehidupan di dunia dan menginternalisasikan dalam dirinya sehingga mampu mengaplikasikan "aturan" tersebut dalam kehidupan sehari-hari dengan sebaik-baiknya merupakan tugas setiap anak dalam perkembangannya. Kebiasaan membuang sampah pada tempatnya, antri, tidak menyeberang jalan dan parkir sembarangan, tidak merugikan atau menyakiti orang lain, mandiri (tidak memerlukan supervisi) serta perilaku-perilaku lain yang menunjukkan adanya pemahaman yang baik terhadap aturan sosial merupakan hasil dari perkembangan kualitas moral dan mental seseorang yang disebut karakter. Berdasarkan perkembangan moral dari Giligan, perkembangan moral dasar dimulai sejak masa kanak-kanak. Dan secara bertingkat terdapat tahapan yang harus dilalui sampai dengan manusia dapat membedakan baikburuk perilaku yang diimplementasikan dalam kehidupan nyata.

Menurut Megawangi (2003), anak-anak akan tumbuh menjadi pribadi yang berkarakter apabila dapat tumbuh pada lingkungan yang berkarakter, sehingga hakikat setiap anak yang dilahirkan suci dapat berkembang segara optimal. 
Mengingat lingkungan anak bukan saja lingkungan keluarga yang sifatnya mikro, maka semua pihak: keluarga, sekolah, media massa, komunitas bisnis, dan sebagainya, turut andil dalam perkembangan karakter anak. Dengan kata lain, mengembangkan generasi penerus berkarakter baik adalah tanggung jawab semua pihak. diperlukan kesadaran dari semua pihak bahwa pendidikan karakter merupakan suatu yang sangat penting untuk segera dilakukan. Kondisi karakter bangsa ini yang memprihatinkan, dan manusia tidak secara alamiah tumbuh menjadi manusia yang berkarakter baik, sebab menurut Aristoteles (dalam Megawangi, 2003), karakter merupakan hasil dari usaha seumur hidup individu dan masyarakat.

\section{Keluarga}

Pandangan para sosiolog bahwa keluarga memiliki peran penting dalam menentukan kemajuan suatu bangsa, sehingga mereka berteori bahwa keluarga adalah unit yang penting sekali dalam masyarakat. Jikalau keluarga-keluarga yang merupakan fondasi masyarakat lemah, maka masyarakat pun akan lemah. Para sosiolog meyakini bahwa berbagai masalah yang terjadi di masyarakat, seperti kejahatan seksual dan kekerasan yang merajalela, serta segala macam perilaku menyimpang merupakan akibat dari lemahnya institusi keluarga.

Keluarga merupakan tempat pertama dan utama bagi pertumbuhan dan perkembangan seorang anak. Menurut Majelis Umum PBB (dalam Megawangi, 2003), bahwa fungsi utama keluarga adalah "sebagai wahana untuk mendidik, mengasuh, dan mensosialisasikan anak, mengembangkan kemampuan seluruh anggotanya agar dapat menjalankan fungsinya di masyarakat dengan baik, serta memberikan kepuasan dan lingkungan yang sehat guna tercapainya keluarga, sejahtera”. Sedangkan menurut pakar pendidikan, William Bennett (dalam Megawangi, 2003), bahwa keluarga merupakan tempat yang paling awal dan efektif untuk menjalankan fungsi Departemen Kesehatan, Pendidikan, dan Kesejahteraan. Apabila keluarga gagal untuk mengajarkan kejujuran, semangat, keinginan untuk menjadi yang terbaik, dan kemampuan-kemampuan dasar, maka 
akan sulit sekali bagi institusi-institusi lain untuk memperbaiki kegagalankegagalannya.

Dari pendapat di atas dapat disimpulkan bahwa keluarga merupakan wahana pertama dan utama bagi pendidikan karakter anak. Apabila keluarga gagal melakukan pendidikan karakter pada anak-anaknya, maka akan sulit bagi institusi-institusi lain di luar keluarga (termasuk sekolah) untuk memperbaikinya. Kegagalan keluarga dalam membentuk karakter anak akan berakibat pada tumbuhnya masyarakat yang tidak berkarakter. Oleh karena itu, setiap keluarga harus memiliki kesadaran bahwa karakter bangsa sangat tergantung pada pendidikan karakter anak di dalam keluarga.

Secara umum, Baumrind mengkategorikan pola asuh menjadi tiga jenis, yaitu: (1) Pola asuh Authoritarian, (2) Pola asuh Authoritative, (3) Pola asuh permissive. Tiga jenis pola asuh Baumrind ini hampir sama dengan jenis pola asuh menurut Hurlock juga Hardy \& Heyes yaitu: (1) Pola asuh otoriter, (2) Pola asuh demokratis, dan (3) Pola asuh permisif. Pola asuh yang diterapkan oleh orang tua dari ciri-ciri masing-masing pola asuh tersebut, yaitu sebagai berikut : Pola asuh otoriter mempunyai ciri: 1) Kekuasaan orangtua dominan; 2) Anak tidak diakui sebagai pribadi; 3) Kontrol terhadap tingkah laku anak sangat ketat; dan 4) Orangtua menghukum anak, jika anak tidak patuh. Pola asuh demokratis mempunyai ciri: 1) Ada kerjasama antara orangtua dan anak; 2) Anak diakui sebagai pribadi; 3) Ada bimbingan dan pengarahan dari orangtua; dan 4) Ada kontrol dari orangtua yang tidak kaku. Pola asuh permisif mempunyai ciri: 1) Dominasi pada anak; 2) Sikap longgar atau kebebasan dari orangtua; 3) Tidak ada bimbingan dan pengarahan dari orangtua; dan 4) Kontrol dan perhatian orangtua sangat kurang.

Menurut Middlebrook (dalam Badingah, 1993), hukuman fisik yang umum diterapkan dalam pola asuh otoriter kurang efektif untuk membentuk tingkah laku anak karena: (a) menyebabkan marah dan frustasi (dan ini tidak cocok untuk belajar); (b) adanya perasaan-perasaan menyakitkan yang mendorong tingkah laku agresif; (c) akibat-akibat hukuman itu dapat meluas sasarannya, misalnya anak menahan diri untuk memukul atau merusak pada waktu ada orangtua tetapi 
segera melakukan setelah orangtua tidak ada; (d) tingkah laku agresif orangtua menjadi model bagi anak.

Hasil penelitian Rohner (dalam Megawangi, 2003) menunjukkan bahwa pengalaman masa kecil seseorang sangat mempengaruhi perkembangan kepribadiannya (karakter atau kecerdasan emosinya). Penelitian tersebut - yang menggunakan teori PAR (Parental Acceptance-Rejection Theory)- menunjukkan bahwa pola asuh orang tua, baik yang menerima (acceptance) atau yang menolak (rejection) anaknya, akan mempengaruhi perkembangan emosi, perilaku, sosialkognitif, dan kesehatan fungsi psikologisnya ketika dewasa kelak.

Dalam hal ini, yang dimaksud dengan anak yang diterima adalah anak yang diberikan kasih sayang, baik secara verbal (diberikan kata-kata cinta dan kasih sayang, kata-kata yang membesarkan hati, dorongan, dan pujian), maupun secara fisik (diberi ciuman, elusan di kepala, pelukan, dan kontak mata yang mesra). Sementara, anak yang ditolak adalah anak yang mendapat perilaku agresif orang tua, baik secara verbal (kata-kata kasar, sindiran negatif, bentakan, dan kata-kata lainnya yang dapat mengecilkan hati), ataupun secara fisik (memukul, mencubit, atau menampar). Sifat penolakan orang tua dapat juga bersifat indifeerence atau neglect, yaitu sifat yang tidak mepedulikan kebutuhan anak baik fisik maupun batin, atau bersifat undifferentiated rejection, yaitu sifat penolakan yang tidak terlalu tegas terlihat, tetapi anak merasa tidak dicintai dan diterima oleh orang tua, walaupun orang tua tidak merasa demikian.

Hasil penelitian Rohner menunjukkan bahwa pola asuh orang tua yang menerima membuat anak merasa disayang, dilindungi, dianggap berharga, dan diberi dukungan oleh orang tuanya. Pola asuh ini sangat kondusif mendukung pembentukan kepribadian yang pro-sosial, percaya diri, dan mandiri namun sangat peduli dengan lingkungannya. Sementara itu, pola asuh yang menolak dapat membuat anak merasa tidak diterima, tidak disayang, dikecilkan, bahkan dibenci oleh orang tuanya. Anak-anak yang mengalami penolakan dari orang tuanya akan menjadi pribadi yang tidak mandiri, atau kelihatan mandiri tetapi tidak mempedulikan orang lain. Selain itu anak ini akan cepat tersinggung, dan berpandangan negatif terhadap orang lain dan terhadap kehidupannya, bersikap 
sangat agresif kepada orang lain, atau merasa minder dan tidak merasa dirinya berharga.

Dari paparan di atas jelas bahwa jenis pola asuh yang diterapkan orang tua kepada anaknya pada akhirnya sangat menentukan keberhasilan pendidikan dan pembentukan karakter anak. Kesalahan dan ketidaksesuaian dalam pengasuhan anak akan berakibat pada kegagalan dalam pembentukan karakter yang baik. Menurut Megawangi (2003) ada beberapa kesalahan orang tua dalam mendidik anak yang dapat mempengaruhi perkembangan kecerdasan emosi anak sehingga berakibat pada pembentukan karakternya, yaitu :

a. Kurang menunjukkan ekspresi kasih sayang baik secara verbal maupun fisik.

b. Kurang meluangkan waktu yang cukup untuk anaknya.

c. Bersikap kasar secara verbal, misainya menyindir, mengecilkan anak, dan berkata-kata kasar.

d. Bersikap kasar secara fisik, misalnya memukul, mencubit, dan memberikan hukuman badan lainnya.

e. Terlalu memaksa anak untuk menguasai kemampuan kognitif secara dini.

f. Tidak menanamkan "good character' kepada anak.

Dampak yang ditimbulkan dari salah asuh seperti di atas, menurut Megawangi akan menghasilkan anak-anak yang mempunyai kepribadian bermasalah atau mempunyai kecerdasan emosi rendah.

a. Anak menjadi acuh tak acuh, tidak butuh orang lain, dan tidak dapat menerima persahabatan. Karena sejak kecil mengalami kemarahan, rasa tidak percaya, dan gangguan emosi negatif lainnya. Ketika dewasa ia akan menolak dukungan, simpati, cinta dan respons positif lainnya dari orang di sekitarnya. la kelihatan sangat mandiri, tetapi tidak hangat dan tidak disenangi oleh orang lain.

b. Secara emosiol tidak responsif, dimana anak yang ditolak akan tidak mampu memberikan cinta kepada orang lain.

c. Berperilaku agresif, yaitu selalu ingin menyakiti orang baik secara verbal maupun fisik.

d. Menjadi minder, merasa diri tidak berharga dan berguna. 
e. Selalu berpandangan negatif pada lingkungan sekitarnya, seperti rasa tidak aman, khawatir, minder, curiga dengan orang lain, dan merasa orang lain sedang mengkritiknya.

f. Ketidakstabilan emosional, yaitu tidak toleran atau tidak tahan terhadap stress, mudah tersinggung, mudah marah, dan sifat yang tidak dapat dipreaiksi oleh orang. lain.

g. Keseimbangan antara perkembangan emosional dan intelektual. Dampak negatif lainnya dapat berupa mogok belajar, dan bahkan dapat memicu kenakalan remaja, tawuran, dan lainnya.

h. Orang tua yang tidak memberikan rasa aman dan terlalu menekan anak, akan membuat anak merasa tidak dekat, dan tidak menjadikan orang tuannya sebagai "role model" Anak akan lebih percaya kepada "peer group"nya sehingga mudah terpengaruh dengan pergaulan negatif.

\section{Sosial Budaya}

Ketahanan sosial budaya adalah kondisi kehidupan sosial budaya bangsa yang dijiwai kepribadian nasional berdasarkan Pancasila yang mengandung kemampuan membentuk dan mengembangkan kehidupan sosial budaya manusia dan masyarakat Indonesia yang beriman dan bertakwa terhadap Tuhan Yang Maha Esa,rukun,bersatu,cinta tanah air,berkualitas maju dan sejahtera dalam kehidupan yang serba selaras, serasi, seimbang serta kemampuan menangkal penetrasi budaya asing yang tidak sesuai dengan kebudayaan nasional.

Integrasi bangsa dapat dilakukan dengan dua strategi kebijakan yakni: asimilationist policy (menghapus sifat-sifat kultural utama dari komunitas kecil yang berbeda menjadi semacam kebudayaan nasional) dan bhinneka tunggal ika policy ( dengan penciptaan kesetiaan nasional tanpa menghapus kebudayaan lokal) (Winarno 2002).

Sosial budaya menunjuk kepada dua segi utama kehidupan bersama manusia, yaitu segi sosial (kemasyarakatan) dan segi budaya (kebudayaan). Sebagai syarat dari kelangsungan hidupnya, manusia harus berhadaptasi dengan lingkungan. Berdasarkan hal tersebut manusia harus mengadakan kerjasama 
dengan sesamanya. Menurut Kansil kelangsungan hidup suatu masyarakat sangat tergantung pada empat unsur penting yakni:

a. Struktur sosial, dalam masyarakat manusia hidup berkelompok dengan tujuan agar mudah dalam menjalankan tugas.

b. Pengawasan sosial, merupakan sistem dan prosedur yang mengatur kegiatan dan tindakan anggota masyarakat serta sistem ipteks empiris yang digunakan untuk menghadapi pengaruh lingkungan. Disamping itu pula mengatur sikap dan tingkah laku manusia ( agama, ideologi, moralitas, sistem hukum).

c. Relasi sosial, masyarakat memerlukan landasan materiil untuk informasi melakukan kegiatan dengan menggunakan transportasi dan landasan sepiritual untuk mengadakan komunikasi dengan menggunakan bahasa atau isyarat.

d. Standar sosial, sebagai ukuran untuk memiliki,meneliti dan menyeleksi sikap yang sebaiknya dilakukan, yang mengandung sistem nilai yaitu kualitas yang diberikan kepada obyek yang berguna dalam memanfaatkan cara untuk mencapai tujuan.

\section{Pembahasan}

Perkembangan karakter pada setiap individu dipengaruhi oleh faktor bawaan (nature) dan faktor lingkungan (nurture). Menurut para developmental psychologist, setiap manusia memiliki potensi bawaan yang akan termanisfestasi setelah dilahirkan, termasuk potensi yang terkait dengan karakter atau nilai-nilai kebajikan. Menurut Confusius bahwa manusia pada dasarnya memiliki potensi mencintai kebajikan, namun bila potensi ini tidak diikuti dengan pendidikan dan sosialisasi setelah manusia dilahirkan, maka manusia dapat berubah menjadi binatang, bahkan lebih buruk lagi (Megawangi, 2003). Oleh karena itu, proses sosialisasi dan pendidikan anak yang berkaitan dengan nilai-nilai kebajikan, baik di dalam keluarga, sekolah, maupun masyarakat (lingkungan) yang lebih luas sangat penting bagi pembentukan karakter seeorang.

Dalam membentuk karakter anak diperlukan syarat-syarat mendasar bagi terbentuknya kepribadian yang baik. Menurut Megawangi (2003), ada tiga kebutuhan dasar anak yang harus dipenuhi, yaitu maternal bonding, rasa aman, 
dan stimulasi fisik dan mental. Maternal bonding (kelekatan psikologis dengan ibunya) merupakan dasar penting dalam pembentukan karakter anak karena aspek ini berperan dalam pembentukan dasar kepercayaan kepada orang lain (trust) pada anak. Kelekatan ini membuat anak merasa diperhatikan dan menumbuhkan rasa aman sehingga menumbuhkan rasa percaya. Menurut Erikson, dasar kepercayaan yang ditumbuhkan melalui hubungan ibu-anak pada tahun-tahun pertama kehidupan anak akan memberi bekal bagi kesuksesan anak dalam kehidupan sosialnya ketika ia dewasa. Dengan kata lain, ikatan emosional yang erat antara ibu-anak di usia awal dapat membentuk kepribadian yang baik pada anak.

Kebutuhan akan rasa aman yaitu kebutuhan anak akan lingkungan yang stabil dan aman. Kebutuhan ini penting bagi pembentukan karakter anak karena lingkungan yang berubah-ubah akan membahayakan perkembangan emosi bayi. Pengasuh yang berganti-ganti juga akan berpengaruh negatif pada perkembangan emosi anak. Menurut Bowlby (dalam Megawangi, 2003), normal bagi seorang bayi untuk mencari kontak dengan hanya satu orang (biasanya ibu) pada tahaptahap awal masa bayi. Kekacauan emosi anak yang terjadi karena tidak adanya rasa aman ini diduga oleh para ahli gizi berkaitan dengan masalah kesulitan makan pada anak. Tentu saja hal ini tidak kondusif bagi pertumbuhan anak yang optimal.

Kebutuhan akan stimulasi fisik dan mental juga merupakan aspek penting dalam pembentukan karakter anak. Tentu saja hal ini membutuhkan perhatian yang besar dari orang tua dan reaksi timbal balik antara ibu dan anaknya. Menurut pakar pendidikan anak, seorang ibu yang sangat perhatian (yang diukur dari seringnya ibu melihat mata anaknya, mengelus, menggendong, dan berbicara kepada anaknya) terhadap anaknya yang berusia usia di bawah enam bulan akan mempengaruhi sikap bayinya sehingga menjadi anak yang gembira, antusias mengeksplorasi lingkungannya, dan menjadikannya anak yang kreatif.

Keberhasilan keluarga dalam menanamkan nilai-nilai kebajikan pada anak sangat tergantung pada pola asuh yang diterapkan orang tua pada anaknya. Pola asuh dapat didefinisikan sebagai pola interaksi antara anak dengan orangtua yang 
meliputi pemenuhan kebutuhan fisik (seperti makan, minum dan lain-lain) dan kebutuhan psikologis (seperti rasa aman, kasih sayang dan lain-lain), serta sosialisasi norma-norma yang berlaku di masyarakat agar anak dapat hidup selaras dengan lingkungannya. Dengan kata lain, pola asuh juga meliputi pola interaksi orang tua dengan anak dalam rangka pendidikan karakter anak.

Melalui pola asuh yang dilakukan oleh orang tua, anak belajar tentang banyak hal, termasuk karakter. Tentu saja pola asuh otoriter dengan karakteristik pola yang menuntut anak untuk patuh terhadap segala keputusan orang tua dan pola asuh permisif yaitu yang cenderung memberikan kebebasan penuh pada anak untuk berbuat; sangat berbeda dampaknya dengan pola asuh demokratis yaitu cenderung mendorong anak untuk terbuka, namun bertanggung jawab dan mandiri. Menunjukkan hasil pendidikan karakter anak. Artinya, jenis pola asuh yang diterapkan oleh orang tua terhadap anaknya menentukan keberhasilan pendidikan karakter anak oleh keluarga.

Studi yang dilakukan oleh Fagan (dalam Badingah, 1993) menunjukan bahwa ada keterkaitan antara faktor keluarga dan tingkat kenakalan keluarga, di mana keluarga yang broken home, kurangnya kebersamaan dan interaksi antar keluarga, dan orang tua yang otoriter cenderung menghasilkan remaja yang bermasalah. Pada akhirnya, hal ini akan berpengaruh terhadap kualitas karakter anak pada saat berinteraksi di lingkungan yang lebih luas lagi.

Pola asuh demokratis tampaknya lebih kondusif dalam pendidikan karakter anak. Hal ini dapat dilihat dari hasil penelitian yang dilakukan oleh Baumrind yang menunjukkan bahwa orangtua yang demokratis lebih mendukung perkembangan anak terutama dalam kemandirian dan tanggungjawab. Sementara, orangtua yang otoriter merugikan, karena anak tidak mandiri, kurang tanggungjawab serta agresif, sedangkan orangtua yang permisif mengakibatkan anak kurang mampu dalam menyesuaikan diri di luar rumah. Menurut Arkoff (dalam Badingah, 1993), anak yang dididik dengan cara demokratis cenderung mengungkapkan agresivitasnya dalam tindakan-tindakan yang konstruktif atau dalam bentuk kebencian yang sifatnya sementara saja. Di sisi lain, anak yang dididik secara otoriter atau ditolak memiliki kecenderungan untuk 
mengungkapkan agresivitasnya dalam bentuk tindakan-tindakan yang merugikan. Sementara itu, anak yang dididik secara permisif cenderung mengembangkan tingkah laku agresif secara terbuka atau terang-terangan.

Unsur budaya di masyarakat juga menentukan kekuatan nasional suatu negara, oleh karena itu pengembangan integrasi nasional menjadi hal yang sangat penting. Integrasi bangsa dapat dilakukan dengan dua strategi kebijakan yakni: asimilationist policy (menghapus sifat-sifat kultural utama dari komunitas kecil yang berbeda menjadi semacam kebudayaan nasional) dan bhinneka tunggal ika policy (dengan penciptaan kesetiaan nasional tanpa menghapus kebudayaan lokal) (Winarno 2002). Indonesia merupakan bangsa yang sangat heterogen rupanya lebih cendrung menggunakan policy Bhinneka Tunggal Ika. Tiap-tiap etnis memiliki budaya dan lokal ginius masing-masing untuk menata kehidupan bermasyarakat, yang notabene sangat ampuh mewujudkan masyarakat yang aman dan damai. Bagi kehidupan nasional tinggal menumbuhkan kesadaran dan kecintaannya terhadap tanah air.

Sosial budaya menunjuk kepada dua segi utama kehidupan bersama manusia, yaitu segi sosial (kemasyarakatan) dan segi budaya (kebudayaan). Sebagai syarat dari kelangsungan hidupnya, manusia harus berhadaptasi dengan lingkungan. Berdasarkan hal tersebut manusia harus mengadakan kerjasama dengan sesamanya. Kelangsungan hidup suatu masyarakat sangat tergantung pada empat unsur penting. Struktur sosial; Hidup dalam kelompok sangat penting memahami nilai-nilai kebersamaan, toleransi dan tanggungjawab sebagai pilar untuk mewujudkan kehidupan yang harmonis. Peran keluarga dalam menanamkan nilai-nilai sosial budaya pada anak-anak menjadi sangat penting. Pengawasan sosial, Adanya pengawasan sosial dari masyarakat terhadap sistem nilai tersebut di atas, hanya mengatur sikap dan tingkah laku manusia, namun pengenalan dan pemahaman terhadap nilai-nilai tersebut oleh anak pertama-tama di diperoleh dari lingkungan keluarga. Keluarga yang memberikan pendidikan karakter pada anak-anaknya, dapat melahirkan generasi yang memiliki karakter yang kokoh sehingga tidak mudah terombang ambing oleh derasnya pengaruh nilai-nilai luar yang tidak cocok dengan kepribadian bangsa. Relasi sosial; 
Indonesia adalah negara multikultur, sehingga budayanya sangat beragam, dalam relasi sosial hendaknya warga-warga suku yang berlainan dapat saling mengerti makna-makna yang diberikan oleh masing-masing suku terhadap ide, perilaku dan benda yang ada ditengah kehidupan mereka, agar tidak terjadi perbedaanperbedaan yang sangat jauh dalam memberikan penafsiran dan tanggapan terhadap apa yang terjadi disekeliling mereka. Setelah ada pemahaman yang cukup baik maka akan terjadi sikap saling menghargai, menghormati satu sama lainnya. Standar sosial; Standar sosial dapat terwujud apabila setiap individu memahami nilai-nilai budaya bangsanya dengan baik. Nilai-nilai tersebut tidak tumbuh dengan sendirinya tetapi harus dibina terus menerus melalui sosialisasi dan pendidikan sejak usia dini.

Dalam naskah Rencana Pembangunan Jangka Menengah Nasional (RPJMN) 2004-2009 telah dimunculkan Program pengembangan nilai budaya untuk memperkuat jati diri bangsa dan memantapkan budaya nasional. Tujuan tersebut dicapai antara lain melalui upaya memperkokoh ketahanan budaya nasional sehingga mampu menangkal penetrasi budaya asing yang bernilai negatif dan memfasilitasi proses adopsi dan adaptasi budaya asing yang bernilai positif dan produktif.

Disamping itu diupayakan pula pembangunan moral bangsa yang mengedepankan nilai-nilai kejujuran, amanah, keteladanan, sportivitas, disiplin, etos kerja, gotong royong, kemandirian, sikap toleransi, rasa malu, dan tanggung jawab. Tujuan tersebut dilaksanakan melalui pengutamaan nilai-nilai budaya pada setiap aspek pembanguanan

\section{Kesimpulan.}

Karakter merupakan kualitas moral dan mental seseorang yang pembentukannya dipengaruhi oleh faktor bawaan (fitrah-nature) dan lingkungan (sosialisasi atau pendidikan-nurture). Potensi karakter yang baik dimiliki manusia sebelum dilahirkan, tetapi potensi tersebut harus terus-menerus dibina melalui sosialisasi dan pendidikan sejak usia dini. 
Meskipun semua pihak bertanggung jawab atas pendidikan karakter calon generasi penerus bangsa (anak-anak), namun keluarga merupakan wahana pertama dan utama bagi pendidikan karakter anak. Untuk membentuk karakter anak keluarga harus memenuhi tiga syarat dasar bagi terbentuknya kepribadian yang baik, yaitu maternal bonding, rasa aman, dan stimulasi fisik dan mental. Selain itu, jenis pola asuh yang diterapkan orang tua kepada anaknya juga menentukan keberhasilan pendidikan karakter anak di rumah. Kesalahan dalam pengasuhan anak di keluarga akan berakibat pada kegagalan dalam pembentukan karakter yang baik.

Kegagalan keluarga dalam melakukan pendidikan karakter pada anakanaknya, akan mempersulit institusi-institusi lain di luar keluarga (termasuk sekolah) dalam upaya memperbaikinya. Kegagalan keluarga dalam membentuk karakter anak akan berakibat pada tumbuhnya masyarakat yang tidak berkarakter. Oleh karena itu, setiap keluarga harus memiliki kesadaran bahwa karakter bangsa sangat tergantung pada pendidikan karakter anak-anak mereka dalam keluarga.

Pendidikan karakter dalam keluarga mempunyai pengaruh yang signifikan terhadap ketahanan sosial budaya bangsa. Generasi yang berkarakter akan mampu menangkal penetrasi budaya asing yang tidak cocok dengan kepribadian bangsa.

\section{Daftar Pustaka}

Badingah, S. (1993). Agresivitas Remaja Kaitannya dengan Pola Asuh, Tingkah Laku Agresif Orang Tua dan Kegemaran Menonoton Film Keras. Program Studi Psikologi - Pascasarjana, UI. Depok.

Coon, Dennis. (1983). Introduction to Psychology : Exploration and Aplication. West Publishing Co.

Hurlock, E.B. 1981. Child Development. Sixth Edition. McGraw Hill Kogakusha International Student.

Kansil,C.S.T, dkk. 2002. Pendidikan Kewarganegaraan Di Perguruan Tinggi, Jakarta, PT. Pradnya Paramita

Megawangi, Ratna. (2003). Pendidikan Karakter untuk Membangun Masyarakat Madani. IPPK Indonesia Heritage Foundation. 
95 - Karakter Anak Dalam Keluarga Sebagai Ketahanan Sosial Budaya Bangsa

Vasta, Ross, at all. (1992). Child Psychology: The Modern Science. John Wiley \& Sons Inc.

Winarno, 2008. Paradigma Baru Pendidikan Kewarganegaraan Panduan Kuliah Di Perguruan Tinggi, Jakarta, PT. Bumi Aksara.

http://nasional.republika.co.id/berita/nasional/umum/15/12/23/nzthuw336-lbh-apikkasus-kdrt-dominasi-kekerasan-perempuan. diakses 20 Aril 2016. 